\title{
Forage yield and quality in elephant grass cv. Pioneiro harvested at different cutting height sand times
}

\author{
Produção e composição química do capim elefante cv. Pioneiro \\ manejado em diferentes alturas de resíduo no ano de implantação \\ da cultura
}

\author{
Danúbia Nogueira Figueira ${ }^{1 *}$; Mikael Neumann²; Robson Kyoshi Ueno ${ }^{3}$; \\ Sandra Galbeiro"; Antônio Vinícius Iank Bueno ${ }^{5}$
}

\begin{abstract}
This study aimed to evaluate the effect of cutting height and harvest time on forage yield and quality in elephant grass (Pennisetum purpureum Schum.) cv. Pioneiro. Experimental plots were arranged in a randomized block split-plot design. The treatments consisted of four residual heights $(30,40,50$, and $60 \mathrm{~cm}$ )and three successive harvest times (January, March, and May 2011). There was a significant interaction between residual height and harvest time for the proportion of stems $(\mathrm{P}<0.05)$ and leaves $(\mathrm{P}<0.01)$ in the forage. A similar result was observed for fresh $(\mathrm{P}<0.01)$ and dry $(\mathrm{P}<0.01)$ forage yield at the first and third harvests. There was a quadratic relationship between dry forage yield and residual height, with a maximum yield of $5738 \mathrm{~kg} \mathrm{ha}^{-1}$ ataresidual height of $50.17 \mathrm{~cm}$ in the second harvest. The increase in residual height from 30 to $60 \mathrm{~cm}$, regardless of harvest time, reduced neutral detergent fiber (NDF)and acid detergent fiber (ADF) and increased crude protein content. Forage yield and quality were highest at $40-50 \mathrm{~cm}$ residual heights.
\end{abstract}

Key words: Forage components. Acid detergent fiber. Neutral detergent fiber. Forage yield. Crude protein.

\section{Resumo}

O experimento foi desenvolvido no município de Guarapuava-PR, com o objetivo de avaliar a produção e a composição química do capim elefante (Pennisetum purpureum, Schum) cv. Pioneiro, manejado em diferentes alturas de resíduo. O delineamento experimental foi em blocos casualizados, em esquema de parcelas subdivididas no tempo, sendo quatro alturas de resíduo: 30, 40,50 e $60 \mathrm{~cm}$ associado a três épocas sucessivas de colheita (Janeiro, Março e Maio de 2010/2011). Houve interação entre altura de resíduo e época de colheita para participação de colmo $(\mathrm{P}>0,05)$ e folha $(\mathrm{P}>0,01)$ na estrutura física da forragem. O mesmo efeito foi observado para produção de massa de forragem fresca $(\mathrm{P}>0,01) \mathrm{e}$ de massa de forragem seca $(\mathrm{P}>0,01)$ na 1 e $3^{\mathrm{a}}$ época de colheita. Houve efeito quadrático na produção

\footnotetext{
${ }^{1}$ Discente, Curso de doutorado em Zootecnia pela Universidade Estadual "Júlio de Mesquita Filho", UNESP, Jaboticabal, SP, Brasil.E-mail danmedvet07@gmail.com

${ }^{2}$ Prof. Dr. em Zootecnia, Universidade Estadual do Centro Oeste, UNICENTRO, Guarapuava, PR, Brasil. E-mail: neumann. mikael@hotmail.com

${ }^{3}$ Discente do curso de doutorado em Zootecnia pela Universidade Federal do Rio Grande do Sul, UFRGS, Porto Alegre, RS, Brasil. E-mail: robsonueno@hotmail.com

${ }^{4}$ Prof $^{\mathrm{a}} \mathrm{Dr}^{\mathrm{a}}$ em Zootecnia, Universidade Estadual de Londrina, UEL, Londrina, PR, Brasil. E-mail: sgalbeiro@gmail.com

5 Discente, Curso de Doutorado em Zootecnia, Universidade Estadual de Maringá, UEM, Maringá, PR, Brasil. E-mail: antonio. iank.bueno@gmail.com

* Author for correspondence
} 
de massa de forragem seca, com ponto de máxima produção de $5.738 \mathrm{~kg} \mathrm{ha}^{-1}$ à altura de resíduo de $50,17 \mathrm{~cm}$ para a segunda época de colheita. Na média geral, a elevação da altura de resíduo do capim elefante de 30 para $60 \mathrm{~cm}$, independente da época de colheita, promoveu redução nos teores de fibra em detergente neutro e fibra em detergente ácido da forragem, além de aumentar os teores de proteína bruta. O melhor equilíbrio entre potencial de produção da massa de forragem seca e composição química da forragem foi obtido quando o capim elefante foi manejado a altura de resíduo de 40 a $50 \mathrm{~cm}$.

Palavras-chave: Estrutura física da forragem. Fibra em detergente ácido. Fibra em detergente neutro. Produção de massa de forragem. Proteína bruta.

\section{Introduction}

Residual height and harvest frequency are two major factors determining yield and quality of forage. Increasing harvest frequency significantly increases yield, but reduces forage quality. Low cutting heights reduce the remaining leaf area and number of apical meristems, directly affecting stand recovery, regrowth, vigor, and persistence (SANTOS et al., 2001a).

However, productivity is linked to the pasture waste time after the harvest of forage, therefore, the growth of a plant after cutting depends on the climate of the favoring and species characteristics (WIJITPHAN et al., 2009). However, as there is a higher proportion of leaves in forage mass, improvements in nutritional quality (EZEQUIEL; FAVORETTO, 2000).

Elephant grass (Pennisetum purpureum Schum.) is a perennial grass with caespitose growth habit and rapidly developing apical meristems, which are prone to being removed at low cutting heights. Thus, removal of apical meristems reduces plant regrowth and yield, and increases stand susceptibility to invasive plants. Moreover, plant regrowth from apical meristems is faster than growth from lateral and basal buds. Thus, improper harvesting management results from continuous removal of apical meristems (SANTOS, 1995).

Proper harvesting management over different harvest seasons is crucial for selecting forage cultivars with high yield potential per unit area with balanced proportions of stems, sheaths, and leaves in the forage to reduce costs with animal feed.
Few studies have evaluated the effect of harvest time on forage yield and quality in elephant grass (SANTOS et al., 2001b; WIJITPHAN et al., 2009; LOUNGLAWAN et al., 2014), but there are few studies that evaluated the best residue height.

This study aimed to evaluate the effect of cutting height and harvest time on forage yield and quality in elephant grass cv. Pioneiro.

\section{Material and Methods}

The study was conducted at the Animal Production Center (NUPRAN), Midwestern State University (UNICENTRO), Guarapuava, Paraná,

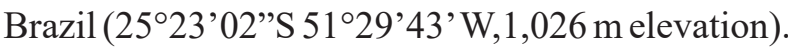

The climateis $\mathrm{Cfb}$ (mesothermal humid subtropical) according to the Köppen classification with mild summers and winters, no dry season and with severe frosts. The mean annual rainfall is 1,944 $\mathrm{mm}$, the annual average minimum temperature 12.7 ${ }^{\circ} \mathrm{C}$, and the annual average maximum temperatureis $23.5^{\circ} \mathrm{C}$. Annual average relative humidity is $77.9 \%$ (IAPAR, 2000).

Elephant grass was planted on October 12,2010in a $256 \mathrm{~m}^{2}$ area divided into $164 \mathrm{x} 4 \mathrm{~m}$ plots $\left(16 \mathrm{~m}^{2}\right.$ each) with a $3 \times 3 \mathrm{~m}\left(9 \mathrm{~m}^{2}\right)$ useful area, which were randomly assigned to four treatments with four replications each.

Elephant grass was sowed manually by planting root cuttings in drills, with $0.5 \mathrm{~m}$ spacing between drills.NPK fertilizer (04-20-20) was applied at $600 \mathrm{~kg} \mathrm{ha}^{-1}$ in the drills at planting based on soil analysis and recommendations in the Liming and Fertilization Manual for the states of Rio Grande 
do Sul and Santa Catarina (CQFS-RS/SC, 2004). The soil in the experimental area isatypical oxisol (POTT et al., 2007) and had the following chemical characteristics at planting (0-20 $\mathrm{cm}$ profile): $0.01 \mathrm{M}$ $\mathrm{CaCl}_{2}: \mathrm{pH} 4.9 ; \mathrm{P}: 3.1 \mathrm{mgdm}^{-3} ; \mathrm{K}^{+}: 0.2 \mathrm{cmol}_{\mathrm{c}} \mathrm{dm}^{-3}$; OM: $44.3 \mathrm{~g} \mathrm{dm}^{2} ; \mathrm{Al}^{3+}: 0.3 \mathrm{cmol}_{\mathrm{c}} \mathrm{dm}^{-3} ; \mathrm{H}^{+}+\mathrm{Al}^{3+}: 6.41$ $\mathrm{cmol}_{\mathrm{c}} \mathrm{dm}^{-3} ; \mathrm{Ca}^{2+}: 4.0 \mathrm{cmol}_{\mathrm{c}} \mathrm{dm}^{-3} ; \mathrm{Mg}^{2+}: 3.4 \mathrm{cmol}_{\mathrm{c}} \mathrm{dm}^{-}$ ${ }^{3}$; andbase saturation (V\%): 54.0\%.

Mechanical weeding practices for weed control, mowing for plant height standardization $(30 \mathrm{~cm})$, and nitrogen topdressing at $150 \mathrm{~kg} \mathrm{ha}^{-1} \mathrm{~N}$ (45-0000 ) in the form of urea were performed at the early stage of crop establishment, on November 15, 2010. Nitrogen fertilization was applied at $75 \mathrm{~kg} \mathrm{~N} \mathrm{ha-1}$ year ${ }^{-1}$ in the form of urea after the first and second harvests.

The treatments consisted of four cutting heights (30, 40, 50, and $60 \mathrm{~cm}$ from the soil) and three successive harvests (January, March, and May 2001; mean light interception: $90-95 \%$, at a mean height of $1.60 \mathrm{~m}$ ). Light interception (LI) measurements were taken immediately before harvesting at four points in each plot using an AccuPARLP-80 digital linear ceptometer (Decagon Devices, Pullman, WA, USA).

Rainfall and mean temperature in the elephant grass growing season were $1041.3 \mathrm{~mm}$ and $19.9^{\circ} \mathrm{C}$, respectively (Figure 1).

Figure 1. Expected and observed precipitation rates and mean temperatures in the elephant grass cv. Pioneiro growing period in the 2010/2011 season. Data from the SIMEPAR/UNICENTRO weather station, Guarapuava, Paraná, Brazil.

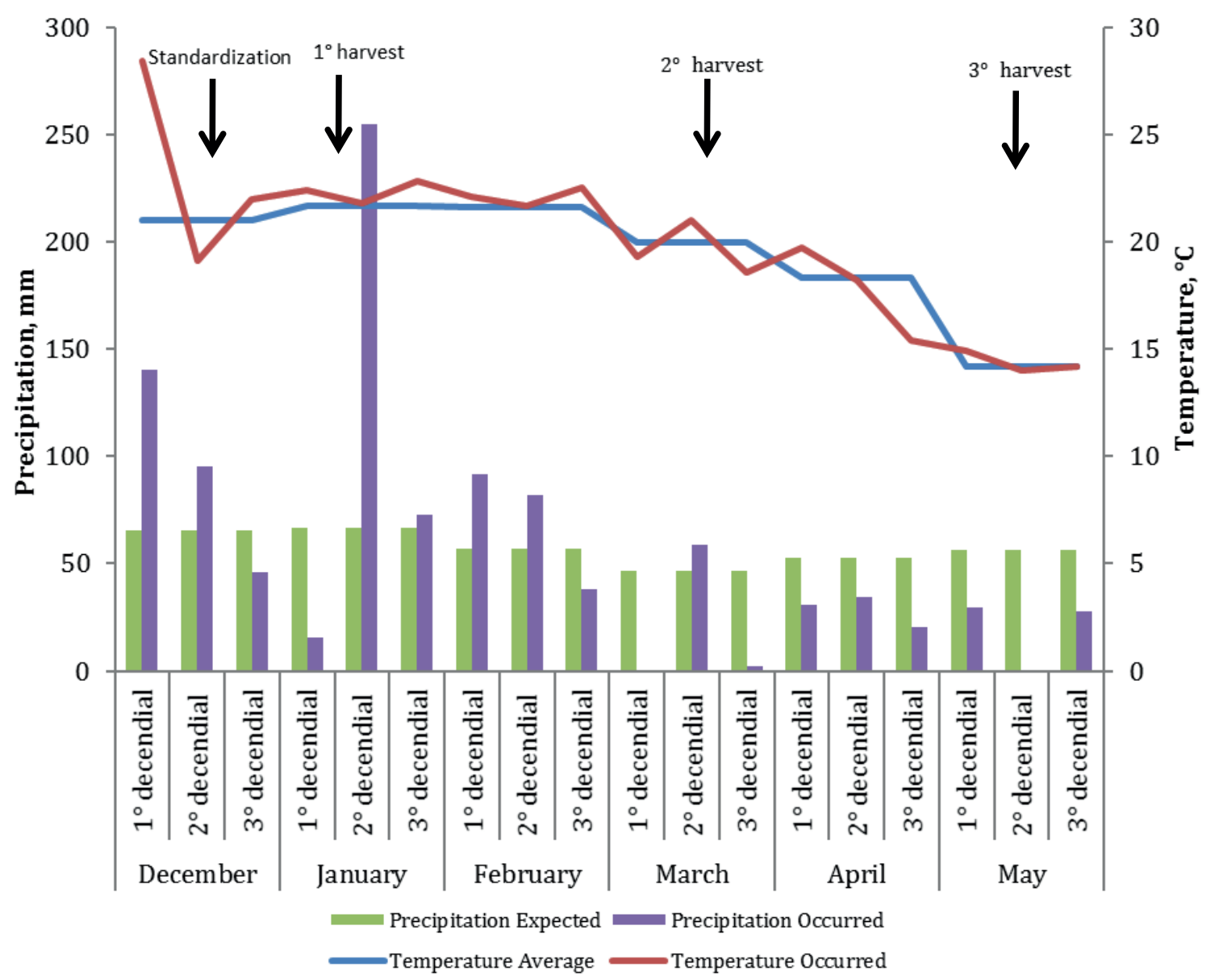


Because the experimental site was located in a region with cooler summer temperatures, only three harvests were conducted, in January, March, and May 2011. Plots were arranged in a randomized block split-plot design, with four residual heights and three consecutive harvest times.

All plots were harvested manually at the four cutting heights to obtain homogeneous composite samples representative of all plant tissues. These composite samples were separated into two 500 g-samples; the first sample was used to determine the proportion of plant parts (stem, sheath, and leaf) and the other was used to determine dry matter content for the estimation of dry matter yield $(\mathrm{kg}$ $\left.\mathrm{DM} \mathrm{ha}^{-1}\right)$. Samples were weighted and pre-dried in an oven with forced air circulation at $55^{\circ} \mathrm{C}$ (AOAC, 1995).

Fresh forage yield was estimated by cutting plants to different residual heights in each plot, which were weighed and used to extrapolate fresh matter yield (kg FM ha-1).

Pre-dried forage samples were used to determine total dry matter content (TDMC) at $105{ }^{\circ} \mathrm{C}$, crude protein $(\mathrm{CP})$ by the micro Kjedahl method, and mineral matter (MM) according to techniques described in AOAC (1995).Neutral detergent fiber (NDF) and acid detergent fiber (ADF) were determined according to the methods of Van Soest et al. (1991) and Goering and Van Soest (1970), respectively.

The data were analyzed using analysis of variance (ANOVA), and means for harvest periods were compared using the Tukey's test at the 5\% significance level. Regression analysis was used to determine the relationship between residual heights and forage variables using the ProcReg procedure in SAS Statistical Software (1993).

\section{Results and Discussion}

Total dry matter and stem, sheath, and leaf dry matter were not affected by residual height or harvest time $(\mathrm{P}>0.05)$ (Table 1). Mean dry matter values for stems $(9.93 \%)$, leaf blades $(14.34 \%)$, and sheaths $(16.95 \%)$ were not affected by cutting height. Dry matter content was highest at a cutting height of $49.64 \mathrm{~cm}(13.04 \%)$.

Mean stem dry matter was highest in the third harvest regardless of residual height $(11.83 \%)$, followed by the second (10\%) and first $(7.92 \%)$ harvests. This result may be explained by the higher water content in young plants, which diminishes as the growth cycle progresses.

Mean sheath dry matter was not affected by harvest time regardless of residual height $(\mathrm{P}>0.05)$ and was highest in the second harvest (16.6\%), followed by the third $(15.56 \%)$ and first $(10.85 \%)$ harvests. No significant differences were observed in mean leaf dry matter across harvests $(\mathrm{P}>0.05)$.

Mean forage dry matter values were higher in the third harvest $(13.86 \%)$ than in the first $(11.58 \%)$ and second (11.46\%) harvests regardless of residual height. This result may be explained by low rainfall at the third harvest (Fig. 1), with rainfall levels far below average for the period.

Acunha and Coelho (1997) evaluated yield inelephant grass cv. Mott at three harvest times and residual heights $(5,10$, and $15 \mathrm{~cm})$ and found that forage dry matter increased from the first to the third harvest $(18.4 \%, 19.0 \%$, and $19.5 \%$, respectively) regardless of residual height. An increase in forage dry matter content is expected over time, because plant growth leads to an accumulation of photosynthates in elephant grass leaves (RAKKIYAPPAN; KRISHNAMOORTHY, 1982).

There was a significant interaction $(\mathrm{P}<0.05)$ between cutting height and harvest time for the proportion of stems, with a linear reduction in stem contribution to forage DM with increasing cutting height in the first harvest (Table 2): for every centimeter increase in residual height there was a $0.33 \%$ reduction in the proportion of stems. 
In the second and third harvests there was a stems at a residual height of $45.65 \mathrm{~cm}$ in the second quadratic relationship between residual height and the proportion of stems, with a minimum $34.3 \%$ harvest and a maximum $37.97 \%$ at a residual height of $41.83 \mathrm{~cm}$ in the third harvest.

Table 1.Forage and stem, sheath, and leaf dry matter in elephant grass cv. Pioneiro harvested at different heights and times.

\begin{tabular}{|c|c|c|c|c|}
\hline \multirow{2}{*}{ Residual height } & \multicolumn{3}{|c|}{ Harvest } & \multirow{2}{*}{ Mean } \\
\hline & first & second & third & \\
\hline \multicolumn{5}{|c|}{ Stem dry matter, $\%$} \\
\hline $30 \mathrm{~cm}$ & 7.33 & 9.47 & 11.61 & 9.47 \\
\hline $40 \mathrm{~cm}$ & 8.02 & 9.55 & 11.90 & 9.82 \\
\hline $50 \mathrm{~cm}$ & 8.82 & 9.61 & 12.34 & 10.25 \\
\hline $60 \mathrm{~cm}$ & 7.53 & 11.53 & 11.47 & 10.17 \\
\hline Mean & $7.92 \mathrm{c}$ & $10.04 \mathrm{~b}$ & $11.83 \mathrm{a}$ & \\
\hline \multicolumn{5}{|c|}{$\mathrm{sDM}=9.93 \%(\mathrm{CV}: 19.44 \% ; \mathrm{P}=0.3039)$} \\
\hline \multicolumn{5}{|c|}{ Sheath dry matter, $\%$} \\
\hline $30 \mathrm{~cm}$ & 10.48 & 16.11 & 15.37 & 13.99 \\
\hline $40 \mathrm{~cm}$ & 11.08 & 15.41 & 15.62 & 14.04 \\
\hline $50 \mathrm{~cm}$ & 10.82 & 15.85 & 15.68 & 14.12 \\
\hline $60 \mathrm{~cm}$ & 11.02 & 19.03 & 15.58 & 15.21 \\
\hline Mean & $10.85 \mathrm{c}$ & $16.60 \mathrm{a}$ & $15.56 \mathrm{~b}$ & \\
\hline \multicolumn{5}{|c|}{$\mathrm{sDM}=14.34 \%(\mathrm{CV}: 19.73 \% ; \mathrm{P}=0.3046)$} \\
\hline \multicolumn{5}{|c|}{$\begin{array}{ll}\text { Leaf dry matter, } \% \\
\end{array}$} \\
\hline $30 \mathrm{~cm}$ & 16.03 & 16.98 & 16.88 & 16.63 \\
\hline $40 \mathrm{~cm}$ & 16.82 & 17.22 & 16.89 & 16.98 \\
\hline $50 \mathrm{~cm}$ & 16.53 & 16.96 & 16.99 & 16.83 \\
\hline $60 \mathrm{~cm}$ & 17.37 & 17.31 & 17.47 & 17.38 \\
\hline Mean & $16.69 \mathrm{a}$ & $17.12 \mathrm{a}$ & $17.06 \mathrm{a}$ & \\
\hline \multicolumn{5}{|c|}{$1 \mathrm{DM}=16.95 \%(\mathrm{CV}: 8.88 \% ; \mathrm{P}=0.5654)$} \\
\hline \multicolumn{5}{|c|}{$\begin{array}{ll}\text { Forage dry matter, } \% \\
\end{array}$} \\
\hline $30 \mathrm{~cm}$ & 10.45 & 10.49 & 13.34 & 11.43 \\
\hline $40 \mathrm{~cm}$ & 11.51 & 11.81 & 14.07 & 12.46 \\
\hline $50 \mathrm{~cm}$ & 13.16 & 11.82 & 13.95 & 12.98 \\
\hline $60 \mathrm{~cm}$ & 11.20 & 11.70 & 14.08 & 12.33 \\
\hline Mean & $11.58 \mathrm{~b}$ & $11.46 \mathrm{~b}$ & $13.86 \mathrm{a}$ & \\
\hline
\end{tabular}

Regression equation $^{1} \quad \mathrm{fDM}=2.9358+0.4071 \mathrm{AR}-0.0041 \mathrm{AR}^{2}\left(\mathrm{CV}: 12.0 \% ; \mathrm{R}^{2}: 0.1291 ; \mathrm{P}=0.0447\right)$

Means in the same row followed by different letters are significantly different (Tukey'stest, $\mathrm{P}<0.05$ ). $\mathrm{CV}=$ coefficient of variation; $\mathrm{R}^{2}=$ coefficient of determination; $\mathrm{P}=$ significance value .

${ }^{1}$ Residual plant height: 30-60 cm.

Mean sheath proportion (16.39\%) was not in the forage was highest in the second harvest affected by residual height at any harvest time (18.26\%) regardless of residual height, followed by $(\mathrm{P}>0.05)$ (Table 2). The mean proportion of sheaths the first $(14.82 \%)$ and third $(16.09 \%)$ harvests. 
There was a significant interaction $(\mathrm{P}<0.05)$ between residual height and harvest time for the proportion of leaves in forage, with a linear increase in leaf proportion in the first harvest: for every centimeter increase in residual height there was $\mathrm{a} 0.34 \%$ increase in the proportion of leaves. In the second and third harvests there was a quadratic relationship between residual height and proportion of leaves, with a maximum $47.76 \%$ at a residual height of $45.97 \mathrm{~cm}$ in the second harvest and a maximum $47.19 \%$ at a residual height of $41.03 \mathrm{~cm}$ in the third harvest.

Table 2.Proportion of stems, leaves, and sheaths in elephant grass cv. Pioneiro harvested at different cutting heights and times.

\begin{tabular}{|c|c|c|c|c|}
\hline \multirow{2}{*}{ Residual height } & \multicolumn{3}{|c|}{ Harvest } & \multirow{2}{*}{ Mean } \\
\hline & first & second & third & \\
\hline \multicolumn{5}{|c|}{ Stem proportion in forage, $\% \mathrm{DM}$} \\
\hline $30 \mathrm{~cm}$ & 39.94 & 39.35 & 33.08 & 37.46 \\
\hline $40 \mathrm{~cm}$ & 37.96 & 34.92 & 37.41 & 36.76 \\
\hline $50 \mathrm{~cm}$ & 32.68 & 34.90 & 35.79 & 34.46 \\
\hline $60 \mathrm{~cm}$ & 30.51 & 38.59 & 25.96 & 31.69 \\
\hline Mean & 35.27 & 36.94 & 33.06 & \\
\hline & \multicolumn{4}{|c|}{$1^{\text {st }}$ time $=50.4125-0.3362 \mathrm{AR}\left(\mathrm{CV}: 18.93 \% ; \mathrm{R}^{2}: 0.2657 ; \mathrm{P}=0.0410\right)$} \\
\hline Regression equation $^{1}$ & \multicolumn{4}{|c|}{$2^{\text {nd }}$ time $=76.8212-1.8626 \mathrm{AR}+0.0204 \mathrm{AR}^{2}\left(\mathrm{CV}: 5.66 \% ; \mathrm{R}^{2}: 0.5443 ; \mathrm{P}=0.0060\right)$} \\
\hline & \multicolumn{4}{|c|}{$3^{\text {rd }}$ time $=-23.8125+2.9537 \mathrm{AR}-0.0353 \mathrm{AR}^{2}\left(\mathrm{CV}: 5.25 \% ; \mathrm{R}^{2}: 0.8863 ; \mathrm{P}=0.0001\right)$} \\
\hline \multicolumn{5}{|c|}{ Sheath proportion in forage, $\% \mathrm{DM}$} \\
\hline $30 \mathrm{~cm}$ & 14.34 & 18.54 & 16.95 & 16.61 \\
\hline $40 \mathrm{~cm}$ & 15.31 & 18.52 & 14.29 & 16.04 \\
\hline $50 \mathrm{~cm}$ & 15.51 & 17.62 & 15.89 & 16.34 \\
\hline $60 \mathrm{~cm}$ & 14.13 & 18.37 & 17.21 & 16.57 \\
\hline Mean & $14.82 \mathrm{~b}$ & $18.26 \mathrm{a}$ & $16.09 \mathrm{~b}$ & \\
\hline \multicolumn{5}{|c|}{$\% \mathrm{DM}=16.39 \%(\mathrm{CV}: 9.82 \% ; \mathrm{P}=0.8315)$} \\
\hline \multicolumn{5}{|c|}{ Leaf proportion in forage, $\% \mathrm{DM}$} \\
\hline $30 \mathrm{~cm}$ & 45.71 & 42.11 & 49.97 & 45.93 \\
\hline $40 \mathrm{~cm}$ & 46.73 & 46.56 & 48.31 & 47.20 \\
\hline $50 \mathrm{~cm}$ & 51.81 & 47.48 & 48.32 & 49.20 \\
\hline $60 \mathrm{~cm}$ & 55.36 & 43.04 & 56.83 & 51.74 \\
\hline Mean & 49.90 & 44.80 & 50.86 & \\
\hline Reoression equation 1 & \multicolumn{4}{|c|}{ 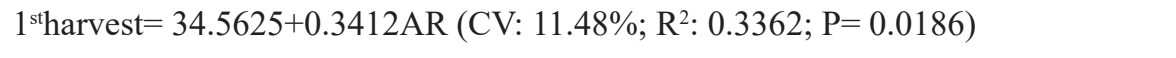 } \\
\hline & \multicolumn{4}{|c|}{$3^{\text {rd }}$ harvest $=89.9612-2.0846 \mathrm{AR}+0.0254 \mathrm{AR}^{2}\left(\mathrm{CV}: 4.22 \% ; \mathrm{R}^{2}: 0.7575 ; \mathrm{P}=0.0001\right)$} \\
\hline
\end{tabular}

Means in the same row followed by different letters are significantly different (Tukey's test, $\mathrm{P}<0.05$ ).

${ }^{1}$ Residual plant height: $30-60 \mathrm{~cm}$.

Overall, elephant grass cv. Pioneiro had a higher proportion of leaves than stems in forage at different residual heights and harvest times. Thus, increasing cutting height significantly increased leaf yield per unit area, and this additional component is the best digestible fraction or of better capacity to be used 
There was a significant interaction $(\mathrm{P}<0.05)$ between residual height and harvest time for fresh forage yield (Table 3). There was a quadratic relationship between residual height and dry forage yield in the three harvests, with estimated maximum yields of $5147 \mathrm{~kg} \mathrm{ha}^{-1}, 5738 \mathrm{~kg} \mathrm{ha}^{-1}$, and $2264 \mathrm{~kg}$ $\mathrm{ha}^{-1}$, at $42.22,50.17$, and $53.24 \mathrm{~cm}$ cutting heights, respectively, in the first, second, and third harvests.

The lowest forage yield in the third harvest may be related to the drop in temperature from the first ten days of April to the last ten days of May (Figure 1). The optimal temperature range for elephant grass production is $20-40{ }^{\circ} \mathrm{C}$ (VILELA, 2009), and the mean temperature in the period before the third harvest was $16.6^{\circ} \mathrm{C}$, which may have negatively affected photosynthesis and plant growth.

Cumulative forage yield in the three harvests was $12,891 \mathrm{~kg} \mathrm{ha}^{-1}$ at $46 \mathrm{~cm}$ residual height, and there was no significant difference in cumulative forage yield across residual heights $(\mathrm{P}>0.05)$. Nascimento et al. (2008) found a mean cumulative yield of $5650 \mathrm{~kg} \mathrm{ha}^{-1}$ for $0,25,50$, and $75 \mathrm{~cm}$ cutting heights in two harvest seasons (spring/summer and fall/winter). The reduced rainfall in the fall/winter harvest negatively affected dry forage yield, when temperatures were more favorable, with no time for proper tillering, thus resulting in lower forage yield than in the current study.

Pontes (2013) evaluated forage yield at two harvest times in elephant grass cv. Napier and found mean yield values of $30,075 \mathrm{~kg} \mathrm{ha}^{-1}$ and $23,200 \mathrm{~kg}$ $\mathrm{ha}^{-1}$ at $30 \mathrm{~cm}$ cutting height for the first and second harvests, respectively.

There was no significant interaction $(\mathrm{P}>0.05)$ between cutting height and harvest time for ash, crude protein, neutral detergent fiber, and acid detergent fiber content (Table 4). Mean ash content (10.4\%; Table 4) was not significantly different across cutting heights $(\mathrm{P}>0.05)$. Conversely, mean ash content was significantly different across harvests $(\mathrm{P}<0.05)$ : ash content was higher in the first harvest $(11.29 \%)$ than in the second $(10.02 \%)$ and third $(9.91 \%)$ harvests, but there was no significant difference between the latter two harvests $(\mathrm{P}>0.05)$.

Table 4. Mean ash, crude protein, neutral detergent fiber, and acid detergent fiber in elephant grass cv. Pioneiro harvested at different cutting heights and times.

\begin{tabular}{|c|c|c|c|c|}
\hline \multirow{2}{*}{ Residual height } & \multicolumn{3}{|c|}{ Harvest } & \multirow{2}{*}{ Mean } \\
\hline & first & second & third & \\
\hline \multicolumn{5}{|c|}{ Ash, \% DM } \\
\hline $30 \mathrm{~cm}$ & 11.98 & 10.35 & 9.94 & 10.76 \\
\hline $40 \mathrm{~cm}$ & 10.82 & 10.01 & 9.77 & 10.20 \\
\hline $50 \mathrm{~cm}$ & 11.04 & 10.22 & 9.95 & 10.40 \\
\hline $60 \mathrm{~cm}$ & 11.34 & 9.50 & 9.96 & 10.27 \\
\hline Mean & $11.29 \mathrm{a}$ & $10.02 b$ & $9.91 b$ & \\
\hline \multicolumn{5}{|c|}{ Ash $=10.40 \%(C V: 8.17 \% ; P=0.3661)$} \\
\hline \multicolumn{5}{|c|}{ Crude protein, \% DM } \\
\hline $30 \mathrm{~cm}$ & 11.94 & 11.42 & 14.13 & 12.50 \\
\hline $40 \mathrm{~cm}$ & 13.42 & 11.76 & 15.94 & 13.71 \\
\hline $50 \mathrm{~cm}$ & 14.19 & 11.97 & 16.10 & 14.09 \\
\hline $60 \mathrm{~cm}$ & 15.15 & 12.51 & 17.47 & 15.04 \\
\hline Mean & $13.68 \mathrm{~b}$ & $11.92 \mathrm{c}$ & $15.91 \mathrm{a}$ & \\
\hline Regression equation $^{1}$ & \multicolumn{4}{|c|}{$\mathrm{CP}=11.9087+0.0377 \mathrm{AR}\left(\mathrm{CV}: 17.27 \% ; \mathrm{R}^{2}: 0.3250 ; \mathrm{P}=0.0219\right)$} \\
\hline
\end{tabular}


Continuation

\begin{tabular}{ccccc}
\hline & \multicolumn{3}{c}{ Neutral detergent fiber, \% DM } \\
$30 \mathrm{~cm}$ & 65.74 & 69.70 & 63.99 & 66.48 \\
$40 \mathrm{~cm}$ & 65.47 & 69.77 & 62.81 & 66.02 \\
$50 \mathrm{~cm}$ & 64.58 & 68.84 & 62.54 & 65.32 \\
$60 \mathrm{~cm}$ & 63.80 & 68.03 & 60.56 & 64.13 \\
Mean & $64.90 \mathrm{~b}$ & $69.09 \mathrm{a}$ & $62.47 \mathrm{c}$ & \\
Regression equation $^{1}$ & $\mathrm{NDF}=66.5695-0.0333 \mathrm{AR}\left(\mathrm{CV}: 5.40 \% ; \mathrm{R}^{2}: 0.3095 ; \mathrm{P}=0.0511\right)$ \\
\hline \multicolumn{5}{c}{ Acid detergent fiber, \% DM } \\
$40 \mathrm{~cm}$ & 43.05 & 47.19 & 41.31 & 43.85 \\
$50 \mathrm{~cm}$ & 42.45 & 46.64 & 40.48 & 43.19 \\
$60 \mathrm{~cm}$ & 39.69 & 45.27 & 39.78 & 41.58 \\
Mean & 39.52 & 44.90 & 37.76 & 40.73
\end{tabular}

Regression equation ${ }^{1}$

$\mathrm{ADF}=43.5638-0.0677 \mathrm{AR}\left(\mathrm{CV}: 8.11 \% ; \mathrm{R}^{2}: 0.4476 ; \mathrm{P}=0.0136\right)$

Means in the same row followed by different letters are significantly different (Tukey's test, $\mathrm{P}<0.05$ ).

${ }^{1}$ Residual plant height: $30-60 \mathrm{~cm}$.

Crude protein content was significantly affected by residual height $(\mathrm{P}<0.05)$. For every centimeter increase in residual height there was a $0.0377 \%$ increase in crude protein content. Additionally, crude protein content also was significantly affected $(\mathrm{P}<0.05)$ by harvest time and was higher in the third harvest $(15.91 \%)$ than in the first $(13.68 \%)$ and second (11.92\%) harvests. This result may be explained by the higher proportion of leaves (Table 3 ) in the third harvest, which increases crude protein content in forage.

Job Queiroz Filho et al. (1998), Martins-Costa et al. (2008), and Santos et al. (2001b) reported mean crude protein levels in elephant grass harvested at different residual heights and harvest times ranging from $7.5 \%$ to $12.9 \%$, which is lower than the range found in this study at different residual heights and harvest times. The minimum level of protein in animal feeds for proper rumen fermentation is 7\% (MINSON, 1984), and all residual heights and harvest times in our study satisfactorily met the minimum protein requirements of ruminants.

The analysis of forage fiber is essential for the formulation of ruminant diets because parameters such as food intake and digestibility, and thus are required to be measured as they correlate with dry matter intake and feed efficiency. The fibrous portion of the plant is a source of carbohydrates that are used as energy by rumen microorganisms, and the minimum amount of NDF required by animals in elephant grass-based diets is 55-60\% (DM basis) (VAN SOEST, 1994).

Neutral detergent fiber content was significantly affected by residual height $(\mathrm{P}<0.05)$ : for every centimeter increase in residual height there was a $0.03 \%$ reduction in NDF content. Also, NDF was significantly different $(\mathrm{P}<0.05)$ across harvests: NDF content was significantly higher in the second harvest $(69.09 \%)$ than in the first $(64.9 \%)$ and third $(62.47 \%)$ harvests.

For every centimeter increase in residual height there was a $0.07 \%$ reduction in acid detergent fiber content (Table 4). Additionally, ADF content was significantly different across harvests $(\mathrm{P}<0.05)$ : ADF was higher in the second harvest $(46.0 \%)$ than in the first (41.18\%) and third (39.83\%) harvests, and there was no difference between the first and third harvests. Finally, NDF and ADF were highest 
in the second harvest due to the higher proportion of stems and sheaths in the forage (Table 2), which increased fibrous material content.

\section{Conclusion}

Taking in consideration the mean values of the physical structure of the forage, production of yield forage, nutritional quality of the forage, for the year it was implemented, we recommend that elephant grass cv. Pioneiro yield are managed at $40-50 \mathrm{~cm}$ residual heights.

\section{References}

ACUNHA, J. B. V.; COELHO, R. W. Efeito da altura e intervalo de resíduo do capim-elefante anão. Pesquisa Agropecuária Brasileira, Brasília, v. 32, n. 1, p. 117-122, 1997.

ASSOCIATION OF OFFICIAL ANALYTICAL CHEMISTS - AOAC. Official methods of analysis. $14^{\text {th }}$ ed. Washington: AOAC, 1995.

COMISSÃO DE QUÍMICA E FERTILIDADE DO SOLO - CQFS-RS/SC. Manual de adubação e de calagem para os estados do Rio Grande do Sul e Santa Catarina. 10. ed. Porto Alegre: Sociedade Brasileira de Ciência do Solo/Núcleo Regional Sul, 2004. 400 p.

EZEQUIEL, J. M. B.; FAVORETTO, F. Efeito do manejo sobre a produção e composição química de perfilhos do capim-colonião (Panicummaximum, Jacq.). Revista Brasileira de Zootecnia, Viçosa, MG, v. 29, n. 6, p. 15961607, 2000.

GOERING, H. K.; VAN SOEST, P. J. Forage fiber analysis: apparatus reagents, procedures and some applications. Washington, D. C.: Agricultural Handbook, 1970. 379 p.

INSTITUTO AGRONÔMICO DO PARANÁ - IAPAR. Cartas climáticas do Paraná. Versão 1.0. Londrina:IAPAR, 2000. 1 CD-ROM.

LOUNGLAWAN, P; LOUNGLAWAN, W.; SUKSOMBAT, W. Effect of cutting interval and cutting height on yield and chemical composition of king Napier grass (Pennisetum purpureum x Pennisetum americanum). Science Direct, Banguecoque, v. 8, n. 3, p. 27-31, 2014.

MARTINS-COSTA, R. H. A.; CABRAL, L. S.; BHERING, M.; ABREU, J. G.; ZERVOUDAKIS, J.
T.; RODRIGUES, R. C.; OLIVEIRA, I. S. Composição química do capim elefante obtido em diferentes idades de resíduo. Revista Brasileira de Saúde Produção Animal, Salvador, v. 9, n. 3, p. 397-406, 2008.

MINSON, D. J. Effects of chemical and physical composition of herbage eaten upon intake. In: Nutritional limits to animal production from pasture. Common Wealth Agriculture, Bureaux, v. 139, n. 2, p. 167-182, 1984.

NASCIMENTO, I. S.; MONKS, L. P.; BATISTA, J. Efeitos de resíduos outonais e hibernais sobre o desempenho produtivo do capim-elefante cv. Cameroon. Revista Brasileira de Ciências Agrárias, Recife, v. 3, n. 2, p. 191-196, 2008.

PEIXOTO, C. P. Curso de fisiologia vegetal. Cruz das Almas: Universidade de Recôncavo da Bahia, 2011. 213p.

PONTES, G. M. Avaliação da produtividade de biomassa de capim elefante e sorgo sacarino no estado do Ceará para uso energético. 2013. Dissertação (Mestrado em Agroenergia) - Curso de Pós-Graduação em Agroernegia, Fundação Getúlio Vargas, São Paulo.

POTT, C. A.; MÜLLER, M. M. L.; BERTELLI, P. B. Adubação verde como alternativa agroecológica para recuperação da fertilidade do solo. Revista Ambiência, Guarapuava, v. 3, n. 12, p. 51-63, 2007.

QUEIROZ FILHO, J. L.; SILVA, D. S.; NASCIMENTO, I. S.; SANTOS, E. A.; OLIVEIRA FILHO, J. J. Produção de matéria seca e qualidade de cultivares de capim elefante (Pennisetum purpureum, Schum). Revista Brasileira de Zootecnia, Viçosa, MG, v. 27, n. 2, p. 262266, 1998.

RAKKIYAPPAN， P.; KRISHNAMOORTHY，K. K. Evaluation of hybrid Napier (N13-21) for its forage quality by cell-wall component analysis. Madras Agricultural Journal, Coimbatore, v. 69, n. 8, p. 523-528, 1982.

SANTOS, E. A.; SILVA, D. S.; QUEIROZ FILHO, J. L. Aspectos produtivos do capim-elefante (Pennisetum purpureum, Schum.) cv. roxo no Brejo Paraibano. Revista Brasileira de Zootecnia, Viçosa, MG, v. 30, n. 1, p. 31-36, 2001a.

Composição química do capim-elefante cv. roxo cortado em diferentes alturas. Revista Brasileira de Zootecnia, Viçosa, MG, v. 30, n. 1, p. 18-23, 2001b.

SANTOS, F. A. P. Manejo de pastagem de capimelefante. In: PEIXOTO, A. M.; MOURA, J. C.; FARIA, V. P. (Ed.). Volumosos para bovinos. 2. ed. Piracicaba: Fundação de Estudos Agrários Luiz de Queiroz, 1995. p. 1-20. 
STATISTICAL ANALYSIS SYSTEM INSTITUTE - SAS Institute. SAS/STAT User's guide: statistics. Version 6. $4^{\text {th }}$ ed. North Caroline: SAS, 1993. v. 2, 943 p.

VAN SOEST, P. J. Nutritional ecology of the ruminant. $2^{\text {th }}$ ed. Ithaca: Cornell University Press, 1994. 476 p.

VAN SOEST, P. J.; ROBERTSON, J. B.; LEWIS, B. A. Methods for dietary fiber, neutral detergent fiber, and nonstarch polysaccharides in relation to animal nutrition. Journal of Dairy Science, Ithaca, v. 74, n. 34, p. 35833597, 1991.
VILELA, H. Série gramíneas tropicais - gênero Pennisetum (Pennisetum purpureum). [S.1.; s.n.], 2009. Disponível em: <http://www.agronomia.com. $\mathrm{br} /$ conteudo/artigos/artigos gramineas tropicais pennisetum_purpureum.htm>. Acesso em: 7 jun. 2014.

WIJITPHAN, S.; LORWILAI, P.; ARKASEANG, C. Effect of cutting heights on productivity and quality of king Napier Grass (Pennisetum purpureumcv. King Grass) under irrigation. Paskiston Journal of Nutrition, Faisalabad, v. 8, n. 8, p. 1244-1250, 2009. 
